\title{
The strength of the urban form
}

\author{
I. Giovagnorio \\ Cagliari University, Italy
}

\begin{abstract}
Cities with more than $75 \%$ of consumption and $85 \%$ of global $\mathrm{CO}_{2}$ emissions are a major problem in our country. The continuous process of urbanization highlights the human need of city and denounces the need to transform the urban settlement from a weak to a strong future sustainability. Urban form and functions are deeply related to the availability of the energy resources in the territory, comparing the behavior of the city to a living organism, dependent on the energy flows in and out. This one-to-one relationship between form and energy sources historically proved that emphasize mutations engender each other on their development and their decline. According to scientific studies, relevant "physical" factors, such as morphology and density, directly affect a settlement's energy behaviour and its microclimate. The uniqueness of each city and their ability to work simultaneously on local and global objectives has driven Europe to indicate cities as a crux and urban design as the appropriate tool for defining the shape and land uses compatible with sustainability goals.

Because of historical ties linking urban form and energy sources, the force switchover to renewable sources raises the question what will be the future shape of the sustainable city. The use of urban design as a tool to influence urban form becomes an essential prerogative to bear on urban form and reach the optimal condition of energy's self-sustainable island.
\end{abstract}

Keywords: urban form, city, energy, sustainability, utopia.

\section{Introduction}

The current energy and environmental condition focus attention on the citysystem. The simultaneous presence of the processes of urbanization, intensification of energy requirements and consequently, the emission of pollutants, make it at the same time the place chosen for the concentration of human activities and the earth system's weak point. 
The process of the world's urbanization, expressing the need of a city [1] for mankind, has been intensified since the early ' 70 s, leading in 2007 to over $50 \%$ of the world population to choose urban living. According to UN data [2], the agglomerations with more than ten million people, within the space of thirty years (1975-2005) have been quintupled, from 3 to 21 today, 15 of which are located in developing countries. A clear symptom of the metropolitanization process [3] that is affecting those countries in which hundreds of people poured daily into cities contributing to a wild urbanization [4] of land, where speed and the extent of the phenomenon grow and expand the big urban centers, making the demarcation of the margins of the agglomeration increasingly blurred. In the opposite way to the phenomena of overcrowding that are involving the Asian and South American territories, the crisis in the western city is dominated by anxiety for its dissolution. The urbanization that has affected the developed countries as a result of the Industrial Revolution has slowly dried up as early as the second half of last century, even to go into reverse, giving life to what is now known as the lost city [5]. Both crises, whether they follow the overcrowding and the dilution phenomenon, are aggravated by energy and environmental effects resulting from the combination of urbanization-fossil sources, whose results deliver to the city the leadership in global consumption which is over $75 \%$, and in pollutant emissions with production of over $85 \%$ of $\mathrm{CO}_{2}$. A record compounded by the knowledge that over $85 \%$ of that $75 \%$ comes from the use of non-renewable fossil fuels in depletion concentrated in limited geographic areas, whose intensive use has shown the fragility of the supply energy system (1970s crisis) and the vulnerability of cities due to the extreme meteorological conditions resulting from environmental effects. This knowledge has reopened the way, starting from 1970s, to an important scientific research intended to study and understanding the energy behavior of the cities, its morphological relations with energy technologies and the testing of new renewable sources.

The birth, in the late $1980 \mathrm{~s}$, of the concept of sustainable development has necessarily led us to think about an alternative urban model that, in addition to incorporating the values of social equity and environmental respect, to discover in the city itself the necessary strength to transform it from a whole energy to a self-sustainable island.

In doing so, as history teaches us and EU policies suggest to us, we will be also involved, through the urban design, the shape of the city, calling upon the narrow two-way link that connects it to sources of supply and the power distribution networks.

\section{Urban form and energy form in history}

The closed link between urban form and energy form allows us to read the whole urban history as a sequence of mutations produced by the development and the consequent decline of energy sources.

The emergence and flourishing of the settlements are dependent on the availability of renewable and energy resources in the area, which, in addition to 
ensuring their survival, have had a deep influenced through the networks and power technologies used, the shape and the functions.

Origin, development and decline of the sources have affected the anthropic use of the territory, as well as settlement and production employment of land that have led to their development, integration and replacement.

Through a quick reading of urban history, we can highlight the morphological characteristics of each period in relation to the sources used:

The "discrete" settlement; is based on human and animal muscle power and on the abundance of wood in the surrounding areas. If the muscle strength was essential for the movement of farm implements and for the transport of goods, wood "as raw material, tools, machinery, equipment, as a final product and as a fuel, was the dominant industrial resource" [6]. The presence and abundance of raw material has deeply influenced the size and the location of settlements, mainly organized in compact forms of small-medium sizes.

In the fourteenth century in Europe, the continued deforestation of wooded land, had alarmed man about the imminent exhaustion of the primary resource and drove him to looking for possible additional sources in water and wind. Also, in this case, the use of water required the settlements to stay near the proximity of the source. The higher energy density and the continuous production of energy from inanimate sources, in larger quantities and in less time, have significantly contributed to the transition from a subsistence economy to a one of market, laying the first foundations for the development of the future industrial society.

Coketown; The shift of the use of coal as energy source has substantially changed the "discrete" settlement model. Its physical and chemical properties allowed, during the Industrial Revolution that occurred in the Nineteenth century, the production of new powerful and innovative technology machinery, such as the steam boiler.

The replacement of waterwheels with boilers turned the historical relationship between the place of extraction of the source and the production and consumption one, freeing the latter from the need to reside imperatively close to the first. The exceptionality of the event and the urban revolution in relation to it can be summed up in a few key points:

- The industry influence on the spatial structure of the settlement. The economic, production, transport and conversion of energy activities influenced and changed the urban form;

- the breaking of the temporal link between solar radiation and daily flow of energy available. The use of fossil energy sources, independent from the obliged presence of the sun, allowed people to have a continuous and uninterrupted flow of energy, released by the time and place of production;

- breaking the link between place of production of energy sources and the place of work and consumption. The birth of the railway made it possible to transfer the raw material at a great distance from the place of extraction. The factories became an active factor in transformation and creation of urban agglomerations, with direct consequences on the degradation of the social 
environment and the urban structure. The two main elements of the new city center were the factory and the slum. They alone make up what was called the city [7].

- $\quad$ The vertical city; the birth of electricity, during the last two decades of the eighteenth century, also broke the last link between the place of production and place of consumption, thanks to the use of the network distribution systems. The electricity, in contrast to earlier sources, was born with a strong urban connotation and it mainly aimed at improving the living conditions in the city. The major technological innovations, such as public lighting system, electric trams and elevators, the network distribution system etc. had a strong influenced on the shape of the city, becoming the structuring elements of the avant-garde modern urban models (one example is the A. Soria Y Mata's Ciudad Lineal, 1882). The scientific and technological innovations completely transformed the way of living and building the city; if the lift has changed the city skyline through the vertical "extrusion" of the building (skyscraper), transport and networks of public services have played a key role in the conformation of the eighteenth century city, becoming engines of a new linear urban development model.

- The horizontal city; in the second half of the eighteenth century the first oil extraction took place. The easiest way of transport along with an energy density superior to $50 \%$ compared with coal benefited its rapid expansion. The combination of oil-electricity has stimulated the technology sector creating, over twenty years, the first internal combustion engine and the mass production of cars. The car sector, supported by political and economic actions, soon boycotted the electric transportation system in favour of one based on tyres, stimulating the infrastructure of the territory by building thousands of miles of highways. The cities are born and flourish economically and physically, on a substrate of fossil fuels [8], with the consequence of diluting the settlement on the territory: suburbs were born, marked with the single family house and roads, intended for owners of vehicles needed to achieve them, which sponsored a new concept of living based on freedom and individual private property values. There appeared the sprawl, still present in our territories, a spokesman of an unbreakable link between oil-dispersion, nowadays extremely critical [9].

Aware of the problems related to the current diluted settlement model and the need to switch to renewable sources with new technological systems, awareness of their direct impact on the formal structure and spatial organization of the city makes us wonder how they will influence the future shape of the city? Can the urban form, and if so, how, to participate actively in the creation of a new sustainable city?

These questions are still unanswered and whose only certainty is the centrality of the city, called to make a difference by implementing incisive quickly measures [10]. 


\section{The relevance of the city}

To emphasize the centrality of cities in the transition to new sustainable models has also contributed to the work done since the middle ' 70 s from international organizations and the European Commission. It was during these years, with the first conferences and community programs that cities attracted world attention on the role they could play in energy and the environment, thanks to the ability to combine, through the accurate action, important goals of local and global urban sustainability.

But the complexity found in the changeover to new sustainable models cannot be attributed only to the moment of transition in which we live, rather than the confusion hidden behind the concept of sustainability. In agreement with statements made by $\mathrm{S}$. Falocco and F. Indovina, the term sustainable development has become over the years an obligatory reference to any document or project action, debasing "profoundly [...] the theoretical and operational importance"[11]. In a short time in-depth examinations were produced and theoretical texts a bit for 'fashion', a bit for the complexity of the term "that, with all the unresolved ambiguity [...] is loaded with expectations" [12] and a bit because it affects different areas of interest (economic, political, social, etc.) involved in the development process with all of its unsolved contradictions.

The term, appeared for the first time during the seventies, has spread globally thanks to the attention and the significance that major international organizations have attributed to it; to the first and best-known definition, which takes its name from the Brundtland Commission itself (1987), have followed many other interpretations which, in turn, have declined and expanded it to their field of interest.

Among the many conjugations, sustainable development gains particular meaning when it's applied to a complex object as the city helping in this case, the construction of a holistic concept in which social equity, "ecological" economy and environmental protection are integrated with a new model of governance based on cooperation and active involvement of all decision-process makers.

This important goal of future urban sustainability cannot disregard involvement of the shape of the settlement, considered to be responsible for the quality of human life, set on the first point of the Rio Declaration (1992). And in order that the goal of a more urban quality should be achieved, the major international organizations have identified in urban design the suitable tool to change and define the structures and land uses compatible with sustainability's principles.

The need to consider the entire urban settlement and not the individual building, is also supported by the result of an interesting study, led by P. De Pascali. Through his work is shown how specific interventions aimed at rationalize energy efficiency of individual buildings "finally inevitably tend to stabilize almost pursued an asymptotic approach toward a final value not further compressible" [13]. 
The urban geometry, from which depend on the ability of daylight and sunlight to reach buildings facades and the use of natural ventilation in dwellings, acts directly on urban microclimate, affecting individuals energy consumptions. According to Givoni [14] "the outdoor temperature, wind speed and solar radiation to which an individual building is exposed is not the regional 'synoptic' climate, but the local microclimate as modified by the 'structure' of the city, mainly of the neighbourhood the building is located".

To act on urban geometry, therefore, means to change its energy consumption; it becomes necessary to understand better its behaviour so that higher levels of performance could be achieved. To do this with regard to European cities, the third in the world rankings for energy consumptions, in which four out of five citizens have chosen to reside, becomes crucial.

\section{The energy behavior of the city-system}

The need to understand the phenomena that characterize the urban structure led us to overcome the sectoral and mechanistic theories to interpret the city in terms of urban organism which is no longer considered as the sum of its parts but as a complex ecosystem based on the comprehension of relationships between its components.

Because of their metabolism, modern cities have been defined by Wright (1958) like "immense mouths". We could assimilate their behavior to that of an energy-intensive and inefficient engine, where a large amount of energy and material is converted at the cost of huge waste of energy.

Their ability to self-organize and react to external disturbances by modifying and reorganizing their own structure (up to a certain threshold) is common with large dissipative systems: "open systems that exchange energy with their environment: they retain their structure thanks to continuous flows of energy available through their system" [15]. Any re-organization, induced by external disturbance, increases the complexity of the structure and consequently its energy needs and vulnerability. If we turn to the thermodynamics in order to understand better the impact of energy transformations, the city can be compared to an open system fed by neg-entropy (high-quality energy and matter) that, once they meet their own needs, releasing a large amount of entropy (low-quality energy/disorder). To the initial input energy, used in part to organize their internal structure (goods, information, services, etc.) and partly to increase its size, follows the release of wastes and pollutants in the environment with the overall decrease of available energy and the deterioration of its quality (the second law of thermodynamics).

This condition of "islands of decreasing entropy" [16] means that today the city will survive and prosper off the environment in which they appear, without taking into adequate consideration its carrying capacity (in 2010 we consumed $150 \%$ of the annual available resources of the planet).

Apply to the "fossil city" [17] the principle of sustainability means to make it able "to meet the needs of its inhabitants within the limits imposed by the need to preserve the integrity and productivity of environmental systems in which its life 
depends on" [18]. Achieve this aim, by urban design, take necessarily action on the spatial relationships that bind the urban form to its energy efficiency, changing the physical factors that influence them (density, geometry and shape of the building, materials, location of functions, transport, green areas, etc.). An expression of these relationships is contained in the urban heat balance equation:

$$
\mathrm{Qr}+\mathrm{Qt}=\mathrm{Qe}+\mathrm{Ql}+\mathrm{Qs}+\mathrm{Qa}
$$

in which the morphology of the settlement (Qr) and the effects of the use of fossil fuels (Qt) appear closely linked to the urban microclimate and environmental conditions. "Size of cities and settlements concentration, geometry and dimensions of building, type of material and type of technologies, distribution of vegetation and degree of soil sealing, location of activities and traffic flows generated by these, modes of transport used, all affect decisively on the effects both of solar radiation that from the uses of fossil fuels, and their combination" [19].

The effects are particularly relevant on the microclimate and on the energy needs of cities located in the middle latitudes. Here the heat trap that is created between the dense parts of the buildings, especially in summer, favors the accumulation of heat and triggers off a circular process between the rate of pollution and rising temperatures of the town center (heat island). The consequence is the exponential increase of the energy demand and to encourage the phenomenon of spatial dispersion to city's surroundings, characterized by marked climatic differences (according to Santamouris et al. [20], differences in temperature between the center and peripheral areas can reach $10^{\circ} \mathrm{C}$ ). Among the main causes that contribute to the heat island are:

- the reduction of green areas on the inside urban areas. The replacement of vegetation with the built-up areas reduces the evapotranspiration of plants and increases the presence of pollutants in the air;

- the high density of urban areas. Natural ventilation is reduced as a result of urban canyons and multiplies reflections between buildings, with a greater absorption and diffusion of heat. While the high density decreases the heat loss of buildings with gains in energy consumption of cooling/heating systems, on the other hand it may increase power consumption due to the higher need for artificial lighting (due to shading of the surrounding surfaces), for forced ventilation systems, distribution systems, etc. In addition, if high density is also accompanied by a high percentage of use of private vehicles, the congestion of the city center dramatically decreases the quality of life and increases air and noise pollution;

- the use of materials with high values of albedo (percentage of direct and diffuse solar radiation that is reflected back to the atmosphere) [21]. The physical and chemical composition of materials promotes the absorption of solar radiation and its releasing during the night; 
- the use of fossil fuels. Their use follow a huge rate of heat loss which concurs to raise the temperature of the city center and the rate of pollution;

Two other functions of T.R. Oke [22], eqns. (2) and (3), confirm the relationship between the island heat and the physical parameters of the city; in the eqn (1), the heat island intensity is directly proportional to the density of the city, while in the eqn (2) is the ratio between the height and distance of the buildings fronts to determine the result of intensity.

$$
\mathrm{dT}=\mathrm{P} 0,25 / 4 \mathrm{U} 0,5
$$

$\mathrm{dT}=$ heat island intensity;

$\mathrm{P}=$ urban population size;

$\mathrm{U}=$ wind speed in the suburban;

$$
\mathrm{dT}=7,54+3,97 \ln (\mathrm{H} / \mathrm{W})
$$

$\mathrm{H} / \mathrm{W}=$ ratio between the high $(\mathrm{H})$ and the distance $(\mathrm{W})$ of buildings.

\section{Call for vision}

"At present there is a plethora of theories emerging about sustainable urban forms. [...] Should it be towards the compact city or not?" [23].

The renewed interest in the compact city as a sustainable urban form has opened an intense international debate. The European Community is one of the major supporters of the efficiency and sustainability of the compact city. The Commission, at the first time with the Green Paper on the Urban Environment (1990) and subsequently with the European Charter II (2008), indicated the dense and compact city as the solution to the gains on urban efficiency and quality. "52. We must rethink our cities around compact and densities urban forms, which require minimal resources for their operation and allow residents to have access, nearness their homes, to the various facilities they need, to services and spaces for leisure, to protect areas and natural parks. We want a city that knows how to save at the level of its resources, its soil, of movement within it, the energy. Only the consistency and firmness of our cities will make the urban space easier, more accessible, more alive to all residents, regardless of their social conditions, their age or health conditions (UE, European Urban Charter II)".

With these guidelines, the strategies pursued by some municipalities, shared by many associations of cities and tested in various community programs, worked in favor of the density with specific actions within the existing urban structure. An acupuncture work face to re-use and conversion with urban infill and re-stitching operations, complemented by the use of alternative clean sources (Solar City/Linz; Hammarby/Stockholm; HafenCity/Hamburg; Zuidas and GWL Terrain/Amsterdam; Nordhavn/Copenhagen, etc.). Otherwise, the new Arab and Asian powers have produced great urban visions (Dongtan, Masdar City, Huai Rou, etc..), sometimes provocative (Super Star-MAD; Gwanggoyo Power 
Centre-MVRDV; Seoul Commune-Mass Studies, etc.) in which the role attributed to technology and at the green areas is too often "a leitmotif of easy success to give a hint to progressive projects that would be otherwise conventional" [24] leaving still open large settings to the reflections on the future shape of the city.

Although it shared the apparent failure of a sectoral approach to the disciplines of urban planning and has instead called for a holistic approach that takes into account the whole urban organism, the correlation of this concept with the compact city model seems not to be shared unanimously (Welbank, Breheny, Thomas and Cousin, Jenks). Neither the approximations with natural ecosystems seem to lead to a certain compact model.

Research in support of a major city density, or to the contrary to a more dispersed area, still show partial (perhaps incomplete) results - given the relative youth and the complexity hidden behind energy issues - to assert with certainty the greater sustainability of one either. Also the incidence of local factors (climate, environment, resources, etc.) and the diversity of energy-environmental issues do not seem to favor a single answer to the problem. The urgency and the extent of the change indicate the importance of the historical moment that we are living, often called "epoch-making". In these moments of transition toward new socio-economic and urban models, man has often put their fears and their expectations in utopian visions that offer alternative views, sometimes concrete and sometimes fantastic, on contemporary issues.

The great urban visions of the first part of the twentieth century were slowly replaced by bureaucracy and complexity of the urban planning practices, flattening its creative capacity. Today the big sustainability issue requires probably a new great urban vision and the promotion of the compact city as possible model to pursue it has rekindled the historical debate between centralist and decentralist [25]. Both can rely on two great masters of architecture, who in 1935 have shown their opposite positions in two urban utopias: Le Ville Radieuse (Le Corbusier) and Broadacre City (Wright). Supporters of the dense city recognize this model:

- the lower use of private vehicles in favor of alternative means of transport (pedestrians, cyclists, public railway, etc.) with heavy savings on fuel consumption and air pollution (Newman and Kenworthy);

- more support for global warming and climate change by reducing $\mathrm{CO}_{2}$ emissions;

- less land consume with protection of farmland and green belt surrounding the settlement;

- $\quad$ improved quality of life, also guaranteed by the proximity of services and the mix of functions;

It would appear that (the quality of urban life) to challenge the victory of the compact city; does not yet seem possible to prove the fact that large density is accompanied by a high quality standard (on the contrary, if you look at the great cities of the third world) and, despite the savings on energy consumption, this does not seem to reach levels that make it acceptable risks of unpopular policies. 
So, quality remains the focal point on which decentralists fight their conviction; according to them:

- the quality of human life can be guaranteed only in small communities in the land. The extreme position enhances the rural values dreaming of a dispersed community based on self-sufficient dwellings supported by telecommunications (electronic cottage - Breheny [25]);

- man still prefers life in the suburb, as confirmed by population's data, there are still many people who leave the city and moved a few miles outside (on this point, however, it is necessary to take into account the policies supported by government and market trends);

- $\quad$ it is unlikely that the compact city is able to protect green belts and farmland curbing its expansion within the city.

Perhaps the solution lies in the middle of the extremes, in a Howard's vision able to apply strategies for urban regeneration and densification, and at the same time to create a network of medium-small settlements, environmental and energy managers, equipped with necessary services and connected by an efficient public transport system.

\section{Conclusion}

The energy and environmental emergencies ask for the integration and the replacement of the old fossil fuels with new sources of clean and renewable energy. As has historically demonstrated, the transition toward new sources and new technologies will transform the spatial form of our cities. It becomes legitimate to ask: what will be the future shape of sustainable cities? Could we, acting through the city shape, contribute to this epochal change towards a better and more efficient management of environmental resources and energy?

Scenarios are still open; although there is a strong tendency to support the compact city as the future urban form, the real evidence on its capability to ensure good quality of life damages the certainty of governments. This big moment of transformation that we are living probably needs time to experiment, even through great utopian visions, on what will be the best roads to undertake. Probably the strength of sustainability lies in the possibility for every community to become self-sufficient by using the resources on its disposal in the environment, in a fair and respectful of the natural time, replacing the current centralized management system with a suitable local one. In this way the opposite urban visions that have historically divided centralist and decentralist, led by two great masters of Wright and Le Corbusier, could find a compromise in a Howard term vision, based on a network of self-sufficient agglomerates of small-medium size held together by an efficient public transport system.

\section{Acknowledgements}

This work is founded by Sardinia Region with founds from PO Sardinia FSE 2007-2013 (L.R.7/2007)"Promotion of scientific research and technological 
innovation in Sardinia". The author wishes to thank the Department of Architecture (University of Cagliari) and particularly, the architect G. Chiri to support the development of research and Carlotta Manca, for her help in translation.

\section{References}

[1] Indovina F., La debolezza della città. Dalla città diffusa all'arcipelago metropolitano, Franco Angeli, Milano 2009.

[2] United Nations, Department of Economic and Social Affairs, http://www.un.org/en/index.shtml.

[3] Veron J., L'urbanizazzione del mondo, Il Mulino Paperbacks, Bologna, p.29; p.73, 2006.

[4] Veron J., L'urbanizazzione del mondo, Il Mulino Paperbacks, Bologna, p.29; p.73, 2006.

[5] Secchi B., La città nel ventesimo secolo, Laterza, Roma, 2005.

[6] Mumford L., La cultura delle città, Einaudi, Milano, 2007.

[7] Mumford L., La cultura delle città, Einaudi, Milano, 2007.

[8] Droege P., La città rinnovabile. Guida completa ad una rivoluzione urbana, Edizioni Ambiente, Città di Castello (PG), 2008.

[9] Gibelli M.C., Forma della città e costi collettivi: l'insostenibile città dispersa, Archivio di Studi Urbani e Regionali, 83, Franco Angeli Editore, Milano, p.19, 2005.

[10] Droege P., La città rinnovabile. Guida completa ad una rivoluzione urbana, Edizioni Ambiente, Città di Castello (PG), 2008.

[11] Falocco S., La ricostruzione di un concetto, Archivio di Studi Urbani e Regionali, 71-72, Franco Angeli Editore, Milano, p.45, 2001.

[12] Indovina F., La città sostenibile: sosteniamo la città, Archivio di Studi Urbani e Regionali, 77, Franco Angeli Editore, Milano, p.5, 2003.

[13] De Pascali Paolo, Città ed energia. La valenza energetica dell'organizzazione insediativa, Franco Angeli, Milano, p. 250-118, 2008.

[14] Ratti C., Baker N., Steemers K., Energy Consumption and urban texture, Energy and Buildings, Elsevier, 2004, online www.sciencedirect.com.

[15] Magnaghi A., Il territorio dell'abitare, Franco Angeli ed., Milano, p. 311, 1994.

[16] Alberti M., Solera G.,Tsetsi V., La città sostenibile, Franco Angeli, Milano, p. 109, 1994.

[17] Butera F., Energia e sviluppo urbano sostenibile, Archivio di Studi Urbani e Rurali, 71-72, Franco Angeli Editore, Milano, p. 103, 2001.

[18] Alberti M., Solera G.,Tsetsi V., La città sostenibile, Franco Angeli, Milano, p. 109, 1994.

[19] De Pascali Paolo, Città ed energia. La valenza energetica dell'organizzazione insediativa, Franco Angeli, Milano, p. 250-118, 2008.

[20] Santamouris M., Papanikolaou N., Livada I., Koronakis I., On the impact of urban climate on the energy consumption of buildings, Solar Energy, vol. 70, 3, Elsevier Science, pp. 201-216, 2001, online www.sciencedirect.com. 
[21] De Pascali Paolo, Città ed energia. La valenza energetica dell'organizzazione insediativa, Franco Angeli, Milano, p. 250-118, 2008.

[22] De Pascali P., Energia, microclima e forma urbana, Gestione Energia, 3, p. 5-11, 2001, online www.fire-italia.it/.

[23] Welbank M., The search for a sustainable urban form, The Compact City, ed. Jenks M., Burton E., Williams K., E\&FN Spon, London and New York, p. 74-82, 1996.

[24] Berrini M., Colonnetti A., Green Life_costruire città sostenibili, Editrice Compositori, Bologna, p. 224, 2010.

[25] Breheny M., The search for a sustainable urban form, The Compact City, ed. Jenks M., Burton E., Williams K., E\&FN Spon, London and New York, p. 13-35, 1996.

[26] Mumford L., Storia dell'Utopia, Ed. Calderini, Bologna, 1969.

[27] Occhiuto M., Verso la città sostenibile. L'esperienza cinese di Huai Rou, Electa, Milano, 2007.

[28] Owen D., GREEN Metropolis. La città più ecologica della campagna?, Egea, Milano 2010.

[29] Zimmermann C., L’era delle metropoli, Il Mulino, Bologna 2004. 